\title{
OVERCOOLING IN OVERLAP AREAS DURING HYDRAULIC DESCALING
}

\author{
PODHLADITEV IN PREKRIVANJE PODROČIJ MED \\ HIDRAVLIČNIM RAZŠKAJANJEM
}

\author{
Michal Pohanka, Helena Votavová \\ Brno University of Technology, Faculty of Mechanical Engineering, Heat Transfer and Fluid Flow Laboratory, \\ Technická 2, 61669 Brno, Czech Republic \\ pohanka@fme.vutbr.cz
}

Prejem rokopisa - received: 2015-07-01; sprejem za objavo - accepted for publication: 2015-07-28

doi:10.17222/mit.2015.164

\begin{abstract}
The production and processing of high-quality grades of steel are connected with the oxidation at high temperatures. Unwanted scales are formed on the steel surface, which is usually heated to over $900{ }^{\circ} \mathrm{C}$. These scales are often removed by hydraulic descaling during the production. In most cases where long, flat products are produced, one row of descaling nozzles is used. As these flat jet nozzles are arranged in a row, the water spray from one nozzle interferes with the spray from the neighboring nozzles. This zone is called an overlap area and often even more scales remain here after the descaling process. An increased amount of the scales left behind results in a lower quality of a final product. A typical configuration with an inclination and twist angle of $15^{\circ}$ was studied. Heat-transfer coefficients (HTC) and surface temperatures were measured in the overlap area and compared with the values obtained from undisturbed areas. It was found that the overlap area is grossly overcooled. The results were compared with a new configuration, where the twist angle was changed to $0^{\circ}$, and it was found that the overcooling was significantly reduced. The temperature measurement showed that an increased thickness of the scales in the overlap area can also be caused by surface overcooling because the scales change the material properties with the temperature, and they are therefore more difficult to remove. The new configuration with the twist angle of $0^{\circ}$ seems promising for improving the quality of hydraulic descaling.

Keywords: scales, steel, water, hydraulic descaling, overlapping, temperature, heat-transfer coefficient, surface

Proizvodnja in predelava visoko kvalitetnih jekel je povezana z oksidacijo pri visokih temperaturah. Nezaželjene škaje nastajajo na površini jekla, ki se ga običajno segreva nad $900{ }^{\circ} \mathrm{C}$. Te škaje se med proizvodnjo pogosto odstranjujejo s hidravličnim razškajanjem. V večini primerov, ko se proizvaja dolge, ploščate proizvode, se uporablja ena vrsta razškajevalnih šob. Ker so šobe $s$ ploščatim curkom razporejene v vrsti, vodni curek iz ene šobe vpliva na vodni curek sosednjih šob. To področje se imenuje področje prekrivanja in pogosto na tem področju ostane več škaje po odškajanju. Povečan delež preostale škaje pa povzroča slabšo kvaliteto končnega proizvoda. Analizirana je bila značilna postavitev z naklonom in kotom zasuka $15^{\circ}$. Na področju prekrivanja je bil izmerjen koeficient prenosa toplote (HTC) in temperatura površine ter primerjava s podatki iz neprizadetih področij. Ugotovljeno je, da so področja prekrivanja močno podhlajena. Rezultati so bili primerjani z novo konfiguracijo, kjer je bil kot zasuka $0^{\circ}$ in ugotovljeno je, da se je podhladitev močno zmanjšala. Meritve temperature so pokazale, da je povečana debelina škaje $\mathrm{v}$ področju prekrivanja lahko tudi posledica podhladitve površine, ker škaja s temperaturo spreminja lastnosti materiala in se jo zato tudi težje odstrani. Zdi se, da bo nova postavitev, s kotom zasuka $0^{\circ}$, omogočila izboljšanje kvalitete hidravličnega ražskajanja.

Ključne besede: škaja, jeklo, voda, hidravlika, razškajanje, prekrivanje, temperatura, koeficient prenosa toplote, površina
\end{abstract}

\section{INTRODUCTION}

Hydraulic descaling (also called high-pressure water descaling) is a very common and effective way to remove unwanted scales on steel products before the hot-rolling process. However, this process is coupled with intense cooling. ${ }^{1,2}$ The intense cooling can also influence the final microstructure. ${ }^{3} \mathrm{~J}$. W. Choi ${ }^{4}$ studied the correlation of the heat-transfer coefficient (HTC) with the impact pressure within a pressure range of 0.48-0.8 MPa and found the following relationship:

$$
h=(44.265 \times I P+7.3670) \times 10^{4}
$$

where $h$ is the convective $\mathrm{HTC}\left(\mathrm{Wm}^{-2} \mathrm{~K}^{-1}\right)$ and $I P$ is the impact pressure (MPa).

Published heat-transfer simulations assume a constant HTC across the width of a sprayed product. ${ }^{5,6}$ How- ever, high-pressure flat-jet descaling nozzles are arranged in one or more rows because the product to be descaled is usually wider than the spray width of a single nozzle, and a more intense cooling occurs in the areas where the surface is sprayed with the water from more than one nozzle. ${ }^{7,8}$ This area is called the overlap area as water streams from two adjacent nozzles, overlapping in the direction parallel to the product movement. The overlap area is often problematic and it is the first place where more remaining scale can be found after descaling. This area is also overcooled. This paper focuses on overcooling in the overlap area for a typical descalingnozzle configuration and compares the results with a new configuration. Measured surface-temperature inhomogeneities are presented as well as convective HTCs in both the undisturbed and overlap areas. 


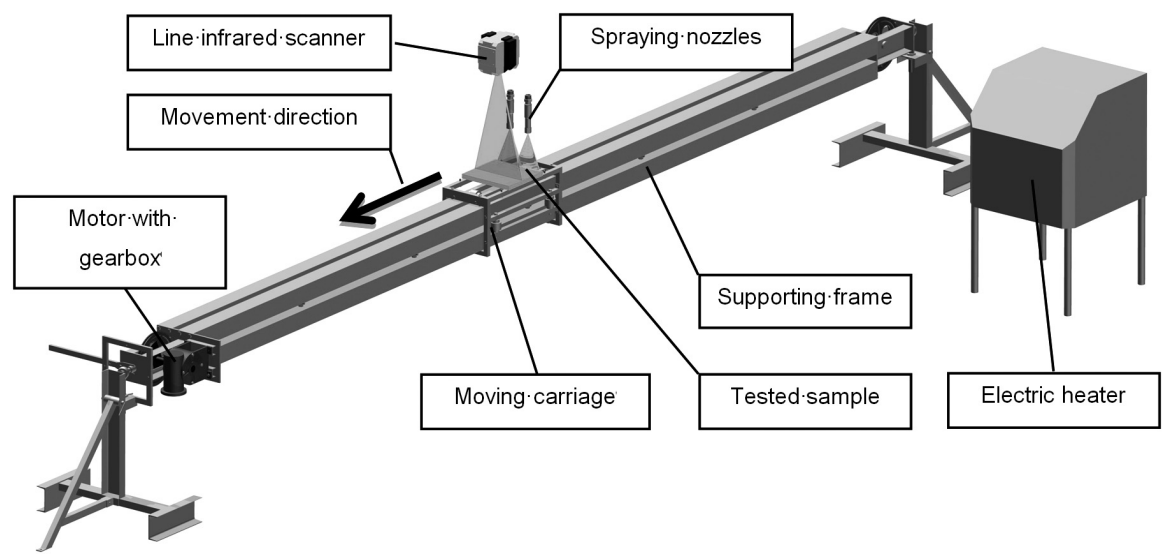

Figure 1: Experimental stand used for experiments

Slika 1: Stojalo uporabljeno pri preizkusih

\section{MEASUREMENTS}

The main purpose of the experiments was to simulate real descaling conditions with more than one spray nozzle and to obtain boundary conditions for numerical simulations.

The experiments were carried out on the experimental stand ${ }^{9}$ shown in Figure 1. An austenitic test plate of $(320 \times 300 \times 25) \mathrm{mm}$ was attached to a moving carriage and heated with an electric heater to over $900{ }^{\circ} \mathrm{C}$. The feed-water pressure was adjusted and the heated test plate moved under the spray nozzles. The velocity of the movement was $0.5 \mathrm{~m} / \mathrm{s}$. The temperature history inside the test plate, the surface temperatures, and the information about the carriage position were recorded during the motion. The surface temperatures were measured using a Raytek RAYTMP501M line infrared scanner located $350 \mathrm{~mm}$ behind the spray nozzles. The temperatures inside the test plate were measured with shielded ungrounded type-K thermocouples. The outer diameter of the shield was $0.52 \mathrm{~mm}$. They were placed in the holes drilled parallel with the surface. The distance of the measurement points from the cooled surface was $0.6 \mathrm{~mm}$. Three thermocouples were installed in the test plate as shown in Figure 2. The thermocouple pitch was $25 \mathrm{~mm}$ and the middle one was in the overlap area.

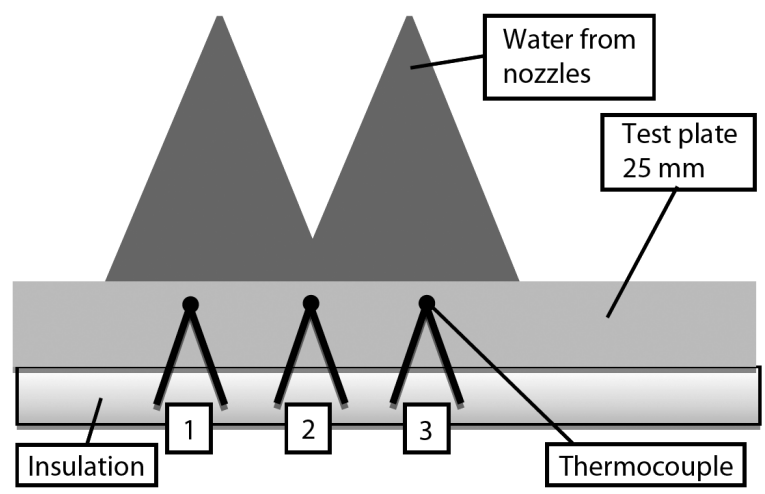

Figure 2: Thermocouple positions for HTC measurements Slika 2: Položaji termoelementov pri HTC meritvah
The measured temperature history from each thermocouple is an input to the inverse computation. ${ }^{10}$ Computed results are the time-dependent HTC and the surface temperature of the cooled side of a test plate. The computed HTC is matched with the position information.

Two high-pressure descaling nozzles at a spray angle of $45^{\circ}$ were used during the measurements. The waterflow rate for each nozzle was $58 \mathrm{~L} / \mathrm{min}$ at $40 \mathrm{MPa}$. The spray height was $55 \mathrm{~mm}$ and the nozzle pitch was $43 \mathrm{~mm}$. Two configurations were tested. The first one was with a $15^{\circ}$ twist angle (Figure 3 ) and the second one was with a $0^{\circ}$ twist angle (Figure 4).

\section{RESULTS}

It was found that the overlap area is extremely overcooled compared to the region cooled by only one spray nozzle. The computed maximum HTC rose from $21 \mathrm{kWm}^{-2} \mathrm{~K}^{-1}$ to $37 \mathrm{kWm}^{-2} \mathrm{~K}^{-1}$ in the overlap area for the $15^{\circ}$ twist angle (Figure 5). The removed heat is even higher, by $99 \%$, at the T2 thermocouple position com-

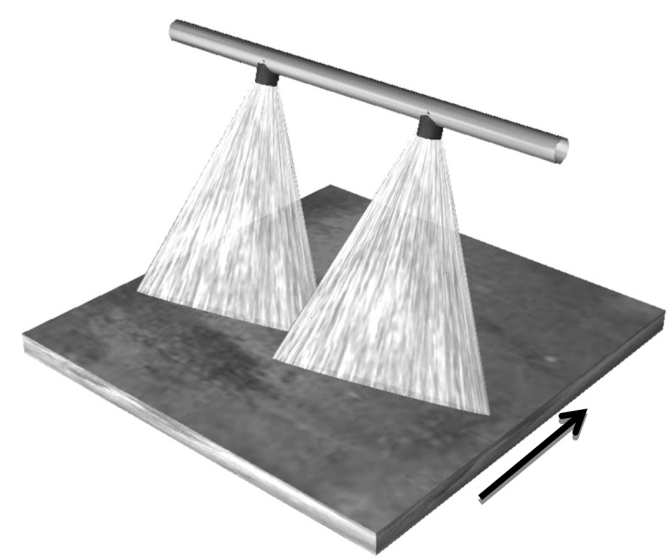

Figure 3: Visualization of the nozzle configuration with the $15^{\circ}$ twist angle. The spray width of each nozzle is $47 \mathrm{~mm}$ and the overlap is $4 \mathrm{~mm}$. The arrow indicates the plate movement direction.

Slika 3: Prikaz postavitve šob s kotom zasuka $15^{\circ}$. Širina curka je 47 $\mathrm{mm}$ pri eni šobi in prekrivanje je $4 \mathrm{~mm}$. Puščica kaže smer gibanja plošče. 


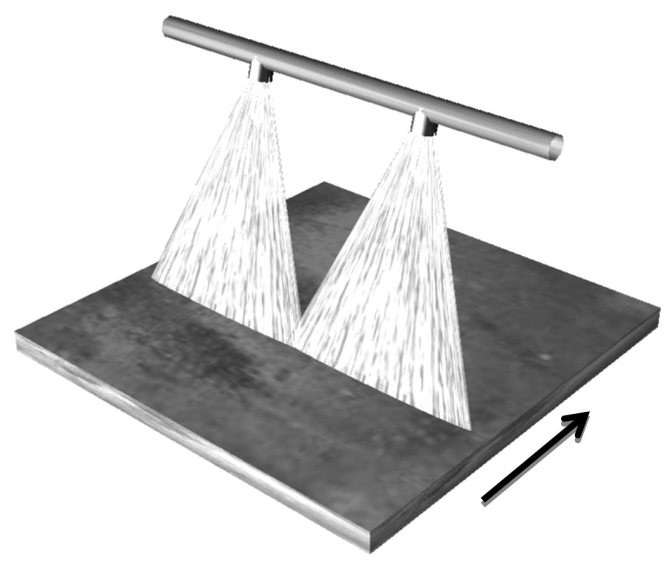

Figure 4: Visualization of the nozzle configuration with the $0^{\circ}$ twist angle. The spray width of each nozzle is $49 \mathrm{~mm}$ and the overlap is $6 \mathrm{~mm}$. The arrow indicates the plate movement direction.

Slika 4: Prikaz postavitve šob s kotom zasuka $0^{\circ}$. Širina curka je 49 $\mathrm{mm}$ pri eni šobi in prekrivanje je $6 \mathrm{~mm}$. Puščica kaže smer gibanja plošče.

pared to thermocouple positions $\mathrm{T} 1$ and $\mathrm{T} 3$. It is also clear that the HTC for T1 is not aligned with the HTC for T3. This is because $\mathrm{T} 1$ and $\mathrm{T} 2$ are not exactly under the spray nozzles (Figure 2) and a non-zero twist angle is used. T1 first passes through the spray on the left, from the left spray nozzle (see the 3D view on Figure 3) and T3 later passes on the right, through the spray from the right nozzle. The HTC peak is much wider for T2. This is because it passes through two sprays from both nozzles in the overlap area. We should see two peaks in the HTC curve but, due to the limitation of the sequential inverse method for computing the HTC from the temperatures measured inside the test plate, the HTC curve is smoothed and these two peaks merge into one peak.

The computed HTC curves for the $0^{\circ}$ twist angle are shown in Figure 6. The curves for T1 and T3 are almost equal to the curves for $\mathrm{T} 1$ and $\mathrm{T} 3$ from the experiment with the $15^{\circ}$ twist angle. The only difference is that they are not shifted because of the $0^{\circ}$ twist angle. The HTC curve for $\mathrm{T} 2$ is also aligned with the HTC curves for T1

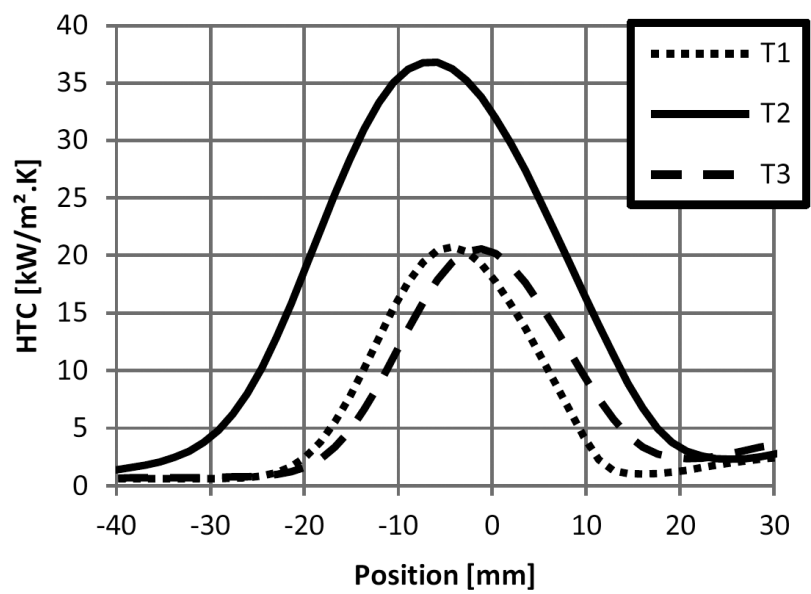

Figure 5: Measured HTC distribution for the $15^{\circ}$ twist angle Slika 5: Izmerjena razporeditev HTC pri kotu zasuka $15^{\circ}$

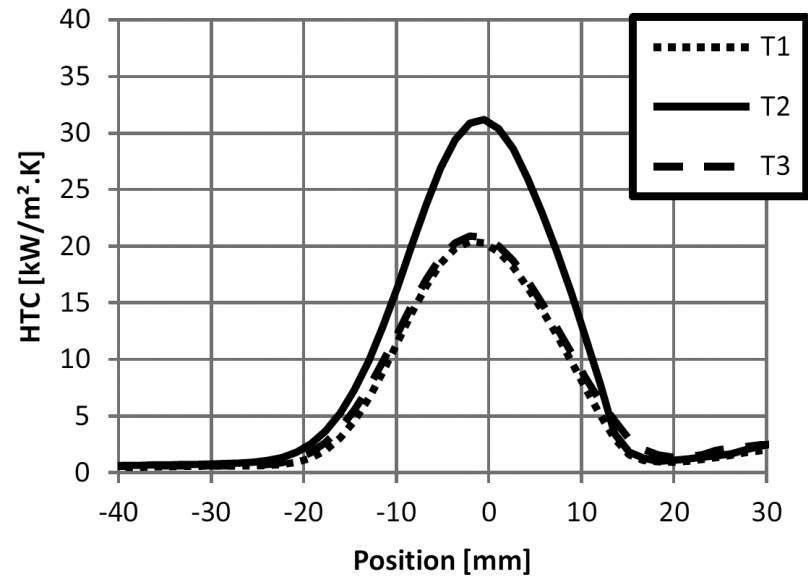

Figure 6: Measured HTC distribution for the $0^{\circ}$ twist angle Slika 6: Izmerjena razporeditev HTC pri kotu zasuka $0^{\circ}$

and $\mathrm{T} 3$ but it is higher by $52 \%$. The removed heat is higher by only $34 \%$ for the T2 thermocouple position, compared to thermocouple positions T1 and T3.

Surface-temperature measurements for both configurations are compared in Figure 7. It is clear that the temperature drop for both configurations is almost the same at the T1 and T3 thermocouple positions. The temperature drop is approximately $40^{\circ} \mathrm{C}$. The major difference is found in the overlap area where the temperature dropped by $79{ }^{\circ} \mathrm{C}$ for the $15^{\circ}$ twist angle and by only $55{ }^{\circ} \mathrm{C}$ for the $0^{\circ}$ twist angle. The measured temperature profile is slightly smoothed by the relatively large measuring point because the minimum diameter of the area measured with the line infrared scanner is about $10 \mathrm{~mm}$.

\section{CONCLUSION}

Two descaling configurations were measured: a typical configuration with a $15^{\circ}$ twist angle and one with a $0^{\circ}$ twist angle. Heat-transfer coefficients for both undis-

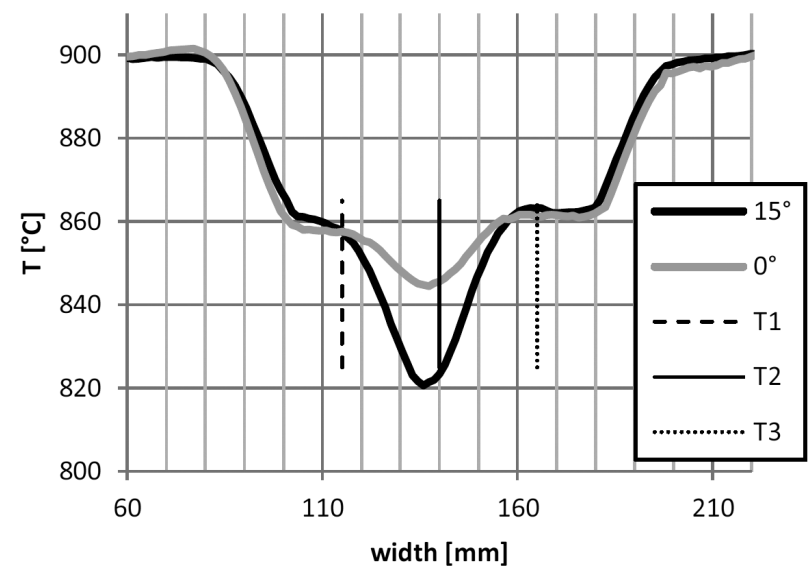

Figure 7: Measured surface temperature across the test plate, $350 \mathrm{~mm}$ behind descaling nozzles

Slika 7: Izmerjena temperatura površine preko plošče, $350 \mathrm{~mm}$ za razškajevalno šobo 
turbed and overlap areas were computed from the measurements as position-dependent values. To give a better idea of the cooling inhomogeneity across the test-plate surface, the temperature profile was measured $350 \mathrm{~mm}$ behind the descaling nozzles.

It was found that the overcooling in the overlap area was very high and the heat removed was almost double that of the typical descaling configurations with the $15^{\circ}$ twist angle. The results from the experiments show that the overcooling can be significantly reduced, by $33 \%$, when the twist angle is set to $0^{\circ}$. In this case, the measured temperature drop was also reduced by $24{ }^{\circ} \mathrm{C}$, which is $30 \%$ of the maximum temperature drop.

The new configuration with the $0^{\circ}$ twist angle seems to be very promising. It does not suffer from the washout effect $^{8}$ and any overcooling is significantly reduced in the overlap area.

\section{Aknowledgement}

This work is an output of the research and scientific activities of project LO1202, with the financial support from the MEYS under the programme NPU I.

\section{REFERENCES}

${ }^{1}$ M. Čarnogurská, M. Př́íhoda, Z. Hajkr, R. Pyszko, Z. Toman, Thermal effects of a high-pressure spray descaling process, Mater. Tehnol., 48 (2014) 3, 389-394
${ }^{2}$ D. C. J. Farrugia, C. Fedorciuc-Onisa, M. Steer, Investigation into mechanisms of heat losses and mechanical descalability during high pressure water descaling, Steel Research International, (2008), 397-402

${ }^{3}$ F. Wang, L. Ning, Q. Zhu, J. Lin, T. A. Dean, An investigation of descaling spray on microstructural evolution in hot rolling, International Journal of Advanced Manufacturing Technology, 38 (2008) 1-2, 38-47, doi:10.1007/s00170-007-1085-x

${ }^{4}$ J. W. Choi, Convective heat transfer coefficient for high pressure water jet, ISIJ International, 42 (2002) 3, 283-289, doi:10.2355/ isijinternational.42.283

${ }^{5}$ R. Colas, Modelling heat transfer during hot rolling of steel strip, Modelling and Simulation in Materials Science and Engineering, 3 (1995) 4, 437-453, doi:10.1088/0965-0393/3/4/002

${ }^{6}$ M. Krzyzanowski, J. H. Beynon, Modelling the behaviour of oxide scale in hot rolling, ISIJ International, 46 (2006) 11, 1533-1547, doi:10.2355/isijinternational.46.1533

${ }^{7}$ H. Votavová, M. Pohanka, Study of Water Jets Collision of High Pressure Flat Jet Nozzles for Hydraulic Descaling, Applied Mechanics and Materials, Switzerland, 821 (2015), 152-158, doi:10.4028/www.scientific.net/AMM.821.152

${ }^{8}$ H. Votavová, M. Pohanka, P. Bulejko, Cooling homogeneity measurement during hydraulic descaling in spray overlapping area, $24^{\text {th }}$ International Conference on Metallurgy and Materials METAL, Ostrava 2015, 1-6

${ }^{9}$ J. Horský, M. Raudenský, M. Pohanka, Experimental study of heat transfer in hot rolling and continuous casting, Materials Science, Testing and Informatics II, Materials Science Forum, 473-474 (2005), 347-354, doi:10.4028/www.scientific.net/MSF.473-474.347

${ }^{10}$ M. Pohanka, P. Kotrbáček, Design of Cooling Units for Heat Treatment, Heat Treatment Conventional and Novel Applications, InTech, Rijeka 2012, 1-20, doi:10.5772/50492 